\title{
Bioprospek
}

https://fmipa.unmul.ac.id/jurnal/index/Bioprospek

\section{ISOLASI DAN IDENTIFIKASI MOLEKULER BAKTERI ANTIMIKROBA PADA SALURAN PENCERNAAN LALAT HIJAU (Chryzomya megachepala)}

\author{
Maria Kanan ${ }^{1}$ \\ ${ }^{1}$ Program Studi Kesehatan Masyarakat Universitas Tompotika Luwuk
}

\section{INFO ARTIKEL}

Terkirim 4 Juni 2018

Diterima 5 Juli 2018

Online 20 September 2018

Keywords.

Chryzomya megachepala

Antimicrobial producing

bacteria

Isolation

Molecular identification

\begin{abstract}
A B S T RA C T
Flies can transmit about 64 types of pathogenic bacteria, in humans. Genus Musca, Chrysomya and Sarcophaga are genera of flies, where members of the species, many of which live around humans. Various researches that have been carried out by researchers found that a fly that carries a number of diseases, also carries antibiotics that neutralize these diseases. Therefore, flies are never attacked by the disease they carry. The purpose of this study was to determine the types of antimicrobial producing bacteria found in the digestive tract of green flies $(C$. megachepala) by molecular identification and to determine the antimicrobial activity produced against several test bacteria. This research is a descriptive experimental study with a pure experimental model to determine the species of antimicrobial producing bacteria in the digestive tract of $C$. megachepala. Digestive tract C. megachepala is isolated on NA (Nutrient Agar) medium. Identification of bacteria using the 16S rRNA gene. Pure isolates obtained are cultured on NB (Nutrient Broth) media. Test antimicrobial activity by diffusion method to use paper disk. One isolate obtained from isolation and molecular identification using the 16S rRNA gene showed that the isolate had a $90 \%$ similarity with Bifidobacterium minimum [NR 044692.2]. These isolates can inhibit Pseudomanas aeroginosa, Staphylococcus aureus, Escherichia coli, and Providencia stuartii. The biggest inhibition zone is against $P$. stuartii.
\end{abstract}

\section{Pendahuluan}

Lalat merupakan Ordo Diptera yang termasuk pada Hexapoda atau insekta, mempunyai jumlah genus dan spesies yang terbesar yaitu mencakup 60-70 \% dari seluruh spesies Arthropoda. Lalat dapat mengganggu kenyamanan hidup manusia, menyerang dan melukai inang (manusia atau hewan) serta menularkan penyakit. Saat ini dijumpai $60.000-100.000$ spesies lalat, tetapi tidak semua spesies perlu diawasi karena beberapa diantaranya tidak berbahaya terhadap kesehatan masyarakat.

Korespondensi: maria.kanan@yahoo.co.id bioprospek@fmipa.unmul.ac.id 
Penularan penyakit dapat terjadi melalui semua bagian dari tubuh lalat seperti: bulu badan, bulu pada anggota gerak, muntahan serta fesesnya. (Depkes RI, 1991).

Berbagai macam genus lalat yang penting antara lain adalah Musca (berbagai jenis lalat rumah), Chrysomya sp. (berbagai jenis lalat hijau) dan Sarcophaga (berbagai jenis lalat daging). Chrysomya sp. banyak dijumpai di Indonesia, terutama di tempat-tempat lembab dan daerah yang berdekatan dengan tempat pembuangan sampah (Departemen kesehatan RI, 1991).

Lalat hidup di tempat yang kotor, sampah, bau ataupun pada suatu bahan yang busuk, sehingga kuman selalu menempel di kaki dan tubuhnya. Lalat ketika hinggap pada makanan, secara tidak langsung makanan tersebut akan terkontaminasi dengan kuman-kuman tersebut. Lalat tetap dapat hidup meski di tubuhnya terdapat berbagai macam bakteri yang berbahaya bagi kesehatan manusia, karena pada salah satu sayapnya terdapat agen penyakit dan pada sayap lainnya ada antimikrobanya (Rachdie, 2007).

Liang et al. (2006), menyatakan serangga dari golongan Hymenoptera, Diptera, Lepidoptera dan Coleoptera yang karena hidupnya di lingkungan yang kotor memiliki kemampuan untuk mengembangkan respons kekebalan yang efisien. Ketika ditulari mikroba patogen, mikroba memproduksi berbagai protein dan peptide antimikroba yang berperan penting dalam memproteksi organism tersebut.. Beberapa macam protein antimikroba dimaksud adalah cecropin, defensin, peptide kaya prolin, peptide kaya glisin, dan lisozim (Boman, 1995 dan Bulet et al., 1999). Senyawa antimikroba ini dapat digunakan untuk mendisain antibiotik dengan spektrum luas bagi manusia (Zasloff, 2002).

Kebutuhan antibiotik, anti fungal, maupun anti kanker baru masih sangat diperlukan, terutama yang efektif melawan bakteri, virus, protozoa, fungi atau kanker. Keberhasilan mendapatkan antibiotik baru dari sumber alami seperti metabolit sekunder dari mikroba telah menimbulkan asumsi bahwa mikroba merupakan sumber senyawa baru yang tidak pernah habis. Pada saat ini antibiotik masih memiliki nilai yang tinggi dan masih sangat dibutuhkan oleh manusia.

Penelitian ini bertujuan untuk mendapatkan isolat bakteri dari saluran pencernaan $C$. megachepala yang dapat menghasilkan senyawa antimikroba untuk pengobatan penyakit, mengetahui spesies bakteri melalui identifikasi molekuler menggunakan gen $16 \mathrm{~S}$ rRNA serta mengetahui aktifitas antimikroba yang dihasilkan isolat.

\section{Metode Penelitian}

Penelitian ini terdiri dari tiga tahap yaitu: 1 . Pengambilan sampel dan isolasi bakteri penghasil antimikroba dari saluran pencernaan lalat; 2). Identifikasi molekuler isolat bakteri penghasil antimikroba menggunakan Gen 16 S rRNA; 3). Uji aktivitas isolat penghasil antimikroba terhadap bakteri uji.

\subsection{Populasi dan Sampel}

Populasi adalah semua spesies lalat $C$. megachepala yang terdapat di pembuangan sampah sementara (TPS) rumah sakit. Sampel untuk isolasi dan identifikasi bakteri penghasil antimikroba yaitu 3-5 ekor lalat $C$. megachepala. Penangkapan lalat dengan menggunakan kantong plastik steril.

\subsection{Prosedur Penelitian}

Tahap 1. Isolasi Bakteri Penghasil Antimikroba dari Saluran Pencernaan C. Megachepala

Alat yang digunakan : Erlenmeyer, petridish, pipet ukur $10 \mathrm{~mL}$, tabung reaksi, rak tabung reaksi, bunsen, pinset, gelas obyek, pipet tetes, mikropipet, jarum ose, mikroskop, timbangan analitik, penangas air, Oven, Laminar Air Flow, inkubator, kulkas, autoklaf.

Bahan yang digunakan : Sampel lalat, $\mathrm{NaCl}$ fisiologis 0,85 \%, NA (Nutrien Agar, aquadest, alkohol $70 \%$, kapas, zat warna 
untuk pengecatan Gram, label, spiritus, aluminium foil.

\section{Prosedur Kerja :}

Disiapkan tabung reaksi yang berisi 10 $\mathrm{ml} \mathrm{NaCl}$ fisiologis steril. Pengambilan sampel saluran pencernaan lalat dilakukan dengan cara menjepit bagian kepala lalat dan bagian ujung abdomen dengan menggunakan pinset steril lalu ditarik. Saluran pencernaan akan kelihatan terbentang, lalu saluran pencernaan tersebut diambil dengan menggunakan ose steril, kemudian dimasukkan ke dalam tabung reaksi yang berisi $10 \mathrm{ml} \mathrm{NaCl}$ fisiologis steril, hancurkan saluran pencernaan tersebut dengan menggunakan ose steril (Kanan, 2017). Dilakukan pengenceran 5x (tingkat pengenceran $10^{-5}$ ). Diambil $1 \mathrm{ml}$ dimasukkan ke dalam cawan petri steril, kemudian dituangi medium Nutrien Agar (NA), sebanyak $15 \mathrm{~mL}$ lalu homogenkan. Biakan disimpan dalam inkubator selama 2 x 24 jam pada suhu $35 \pm 2^{0} \mathrm{C}$. Diamati zona bening yang terbentuk di sekitar koloni yang tumbuh. Bila terdapat zona bening berarti mikroba tersebut dapat menghasilkan senyawa antimikroba. Koloni yang berbeda digores kembali ke dalam media lempeng Nutrien Agar lalu inkubasi selama 1 x 24 jam pada suhu $35 \pm 2^{\circ} \mathrm{C}$, sampai diperoleh biakan murni. Diamati bentuk morfologinya (bentuk koloni, warna koloni). Koloni yang tumbuh diambil satu ose dipindahkan ke media padat miring (NA) sebagai isolat murni. Untuk mengetahui apakah isolat mikroba tersebut dapat menghasilkan senyawa antimikroba maka dilakukan uji terhadap beberapa bakteri patogen yaitu: Pseudomanas aeroginosa, Staphylococcus aureus, Escherichia coli, dan Providencia stuarti yang merupakan bakteri hasil isolasi dari lalat. Isolat bakteri dikultur (1-7 X 24 jam) dalam medium cair (Nutrient Broth) dan bakteri uji dalam medium padat (NA). Bakteri uji diencerkan dalam larutan $\mathrm{NaCl}$ fisiologis steril dengan standart Mac-Farland 0,5 , kemudian dipipet ke dalam cawan petri steril sebanyak $0,1 \mathrm{ml}$ lalu dituangi dengan medium NA, dihomogenkan dan biarkan membeku. Paper disk berukuran $6 \mathrm{~mm}$ direndam selama 10 menit dalam kultur mikroba. Paperdisk diletakkan secara aseptis pada permukaan medium NA yang telah berisi mikroba uji, inkubasi pada suhu $35 \pm 2^{\circ} \mathrm{C}$ selama $1-2 \times 24$ jam. Bila terdapat zone bening menunjukkan bahwa isolat tersebut dapat menghasilkan senyawa antimikroba yang dapat menghambat pertumbuhan mikroba uji. Isolat terpilih kemudian diidentifikasi, dengan melakukan pengamatan karakter fenotip : Morfologi sel (bentuk dan sifat terhadap pewarnaan gram). Identifikasi isolat bakteri penghasil antimikroba dilakukan secara molekuler.

\section{Tahap 2. Identifikasi Molekuler Isolat Bakteri Penghasil Antimikroba Menggunakan Gen 16 S rRNA. \\ Alat yang digunakan : untuk analisis DNA} isolat bakteri antara lain: Eppendorf $10 \mu \mathrm{l}-$ $200 \mu \mathrm{l}$, Tips 1-1000 $\mu \mathrm{l}$, Thermoblock (Biosan), Timbangan analitik, Sentrifuse 5430 R Eppendorf, Vortex Biosan, Master cycler Pro S (Biosan), Nanophotometer (Implen), Automatic elektroforesis Qiaxel (Qiagen).

Bahan yang digunakan : untuk ekstraksi dan purifikasi DNA bakteri Presto ${ }^{T M}$ Mini gDNA Bacteria Kit Geneaid, 16S, Primer Gen 16S rRNA (App. 425 bp): (Cognato dan Vogler, 2001), alkohol 95\%, KIT PCR solis biodine (USA), KIT elektroforesis automatic dan DNA screening KIT (Qiagen). Sekuensing menggunakan jasa sekuensing First Base Singapura.

\section{Prosedur Kerja :}

\section{Preparasi Isolat Bakteri}

Sebelum dilakukan Ekstraksi dan Purfikasi DNA, isolat bakteri yang telah dimurnikan sebelumnya diinokulasikan ke dalam media penyubur umum (Nutrient Agar) dan diinkubasikan selama 1 x 24 jam dengan suhu kamar. Koloni bakteri yang tumbuh dijadikan sumber suspensi sel bakteri untuk analisis DNA.

\section{Ekstraksi dan Purifikasi DNA}

Suspensi bakteri dari kultur murni disiapkan secara aseptik. DNA isolat bakteri 
diekstraksi dengan Presto ${ }^{T M}$ Mini gDNA Bacteria Kit Geneaid dengan prosedur penelitian bakteri gram positif menurut protokol Kit. Tahapan ekstraksi dan purifikasi DNA dimulai dengan tahap Preparasi Sampel (1), Tahap Lysis (2), Tahap DNA Binding (3), Tahap Washing (4) dan Tahap Elution (5).

\section{Analisis Konsentrasi dan Kemurnian DNA}

Hasil ekstraksi DNA total selanjutnya dianalisis konsentrasi dan kemurnian dengan menggunakan UV/VIS Spectrometer Lambda 35 Perkin Elmer. Kemurnian DNA dapat dilihat dengan nilai rasio A260/A280 antara 1,8 - 2,0 nm. Apabila $<1,8$ berarti terkontaminasi dengan protein dan atau komponen cemaran derivate protein yang mempengaruhi molekul DNA, dan jika >2,0 berarti terkontaminasi dengan RNA (Protokol Kit), dengan rumus Konsentrasi dan Kemurnian DNA sebagai berikut:

Konsentrasi DNA $=$ Absorbansi $260 \times 50$ (Barbosa et al. 2005)

Kemurnian DNA $=\frac{\text { Absorbansi } 260}{\text { Absorbansi } 280}$

\section{Amplifikasi Gen 16S rRNA Metode PCR}

DNA hasil ekstraksi diamplifikasi menggunakan metode PCR menggunakan mesin PCR Master cycles pro s Eppendorf. Proses PCR menggunakan 2x MyTaq HS Red Mix Bioline dan Primer 16S rRNA yang digunakan dalam proses amplifikasi secara PCR adalah: 16S (App. 425 bp) (Cognato dan Vogler, 2001).

16sA (5'CGC CTG TTT AAC AAA AAC AT 3') (Foward)

16sB2 (5`TTT AAT CCA ACA TCG AGG 3’) (Reverse)

Dengan kondisi PCR denaturasi awal $72^{\circ} \mathrm{C}$ selama 50 detik kemudian denaturasi berikut $94^{\circ} \mathrm{C}$ selama 30 detik. Annealing $49^{\circ} \mathrm{C}$ selama 40 detik, extension $72^{\circ} \mathrm{C}$ selama 50 detik, final extension $72^{\circ} \mathrm{C}$ selama 5 menit. Jumlah siklus sebanyak 35 kali.
Visualisasi Produk PCR dengan Automatic Electrophoresis Qiaexel

Menggunakan KIT DNA Screening Qiagen (Qiaxel). Prosedur kerja disesuaikan dengan protokol KIT.

\section{Sekuensing}

Sekuensing menggunakan ABI PRISM 3730xl Genetic Analyzer Develop by Applied Biosystems, USA, melalui jasa sekuensing FIRST BASE Singapura.

Pengolahan Data Sekuens dan Analisis Data

Output sekuensing dari FIRST BASE Singapura yaitu dalam bentuk file seq dianalisis menggunakan software Bioinformatika Geneious 10.1.3. Hasil pembacaan dengan Geneious 10.1.3 adalah kromatogram sekuens, urutan basa gen $16 \mathrm{~S}$ rRNA bakteri termofilik atau disebut sekuens dan karakteristik sekuens. Sekuens gen 16S rRNA bakteri yang diperoleh selanjutnya digunakan untuk analisis penyejajaran menggunakan metode BLAST (Basics Local Alignment Searching Tools) secara online pada situs NCBI (https://blast.ncbi.nlm.nih.gov/Blast.cgi).

Tahap 3. Uji Aktivitas Isolat Penghasil Antimikroba Terhadap Bakteri Uji

Fermentasi dan Uji Aktivitas Antimikroba yang Dihasilkan oleh Isolat Alat yang digunakan : Erlenmeyer, petridish, pipet ukur $10 \mathrm{~mL}$, tabung reaksi, rak tabung reaksi, bunsen, pinset, gelas obyek, pipet tetes, mikropipet, jarum ose, cuvet, mikroskop, timbangan analitik, penangas air, Oven, Laminar Air Flow, shaking incubator, kulkas, autoklaf, sentrifuge.

Bahan yang digunakan : $\mathrm{NaCl}$ fisiologis 0,85\%, NA (Nutrien Agar), Nutrient Broth (NB), aquadest, alkohol $70 \%$, kapas, label, spiritus. Isolat bakteri penghasil antimikroba dari lalat, isolat bakteri uji.

\section{Cara kerja :}

\section{Fermentasi Pada Medium Produksi}

Isolat yang telah diperoleh dan diduga menghasilkan senyawa antimikroba 
diremajakan kembali. Diambil 1 Ose dan inokulasikan ke dalam medium fermentasi (Nutrient Broth).lalu inkubasi pada suhu kamar selama 1-3 x 24 jam sambil dishaker dengan intensitas $170-200 \mathrm{rpm}$. Kemudian disentrifuge dengan kecepatan1000 rpm selama 15 menit. Filtrat yang diperoleh siap untuk diuji aktivitasnya terhadap bakteri uji.

Tahap 4. Uji Aktivitas Antimikroba Hasil Fermentasi Terhadap Bakteri Uji dengan Metoda Difusi Agar (Metode Difusi Kirby - Bauer)

Bakteri uji diremajakan pada medium NA (Nutrien Agar) selama 1 x 24 jam. Bakteri uji diencerkan dengan larutan $\mathrm{NaCl}$ fisiologis 0,85\% dengan standar MacFarland 0,5. Diambil 0,1 ml bakteri uji dimasukkan ke dalam cawan petri steril, kemudian dituangi medium NA steril yang masih cair, dihomogenkan dan dibiarkan sampai membeku. Paperdisk berukuran 6 $\mathrm{mm}$ direndam dalam filtrat hasil sentrifuge selama 10 menit. Paperdisk diletakkan secara aseptis pada permukaan medium NA yang telah berisi bakteri uji, inkubasi pada suhu $35 \pm 2{ }^{\circ} \mathrm{C}$ selama 24 jam. Diukur zona bening yang terbentuk dengan menggunakan mistar sorong (Prescott et al. 2002).

\section{Hasil dan Pembahasan}

\section{Isolasi Bakteri Penghasil Antimikroba dari Saluran Pencernaan $C$. megachepala}

Hasil isolasi bakteri penghasil antimikroba dari saluran pencernaan $C$. megachepala yang terdapat di TPS rumah sakit diperoleh satu isolat. Berdasarkan identifikasi morfologi koloni menunjukkan bahwa isolat tersebut koloninya berwarna putih dan bentuk tidak teratur. Berdasarkan pewarnaan Gram, diperoleh bentuk sel bulat dan termasuk Gram positif.
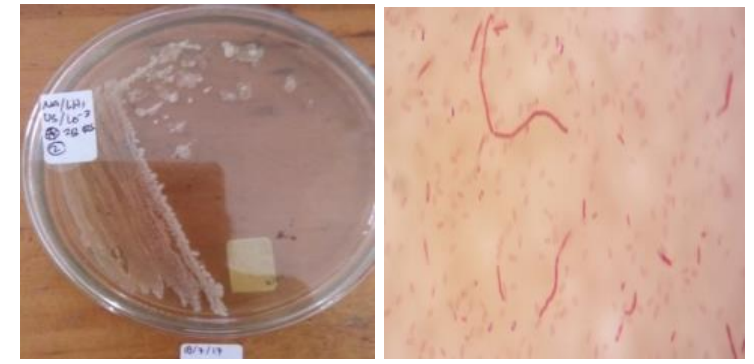

Gambar 1. Morfologi Koloni dan Hasil Pewarnaan Gram

\section{Identifikasi Molekuler Isolat Bakteri Penghasil Antimikroba Menggunakan Gen 16 S rRNA}

a. Ekstraksi dan Purfikasi DNA total

DNA total isolat bakteri diisolasi menggunakan Presto TM Mini gDNA Bacteria Kit Geneaid. Kultur isolat murni digunakan sebagai sumber sel untuk ekstraksi dan purifikasi DNA total. Volume DNA total isolat adalah $100 \mu \mathrm{l}$. Berdasarkan analisis kemurnian diperoleh sebaran kemurnian DNA total adalah 1,80. Sedangkan konsentrasi DNA total adalah $41,20 \mu \mathrm{g} / \mu \mathrm{l}$.

Konsentrasi dan kemurnian DNA total bakteri sangat berpengaruh terhadap keberhasilan amplifikasi gen 16S rRNA dengan metode PCR (Simanjuntak dan Mokosuli; Manuahe et.al., 2015). Konsentrasi optimal DNA total berdasarkan protokol kit yang digunakan adalah $30 \mu \mathrm{g} / \mu \mathrm{l}$ sampai dengan $60 \mu \mathrm{g} / \mu \mathrm{l}$, sedangkan untuk kemurnian DNA total adalah 1,80 (A260/A280). Dengan demikian, konsentrasi DNA isolat bakteri yang diperoleht tergolong baik. Kemurnian DNA total yang diperoleh tergolong cukup baik. Modifikasi protokol pada tahap perendaman protenase-K dan RNAase terbukti meningkatkan konsentrasi akan tetapi tidak pada kemurnian DNA total. Walaupun demikian, kualitas DNA total bakteri sebagai templete akan diketahui setelah dilakukan amplifikasi gen $16 \mathrm{~S}$ rRNA dengan metode PCR. 
b. PCR dan Visualisasi Amplikon Gen Target dengan Elektroforesis

Visualisasi amplikon gen 16S rRNA isolat bakteri yaitu pada $780 \mathrm{bp}$. Berdasarkan pita yang terbentuk, mengindikasikan bahwa proses amplifikasi gen 16S rRNA berhasil pada isolat bakteri. (Gambar 2).

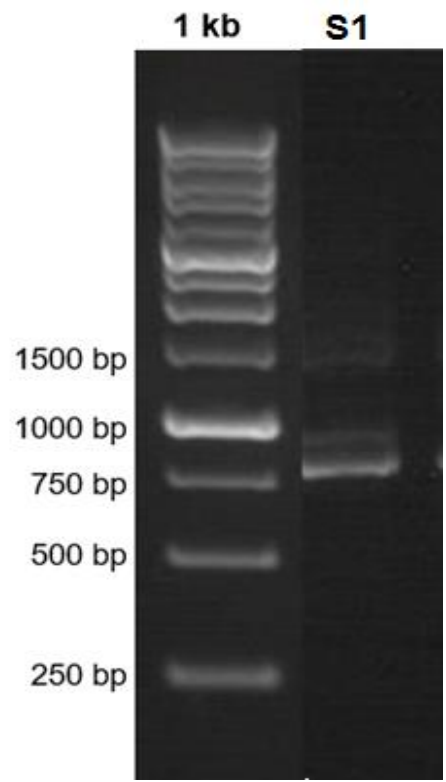

Gambar 2. Visualisasi amplikon gen $16 \mathrm{~S}$ rRNA isolat bakteri penghasil antimikroba dari saluran pencernaan lalat C. megachepala

\section{c. Sekuensing}

Pengurutan nukleotida gen 16 S RNA dari isolat bakteri dilakukan dengan sekuensing. Produk sekuensing dalam bentuk file seq, dari Laboratorium FIRST BASE Singapura, dibaca menggunakan program Geneous (Gambar 3). Daerah konsensus dari sekuens gen 16S rRNA diperoleh menggunakan Program Bioedit.

Sekuens konsensus gen $16 \mathrm{~S}$ rRNA isolat digunakan untuk penyejajaran dengan metode BLAST. Analisis penyejajaran sekuens gen 16S rRNA isolat bakteri penghasil antimikroba yang berhasil diisolasi menunjukkan kemiripan $90 \%$ dengan Bifidobacterium minimum [NR 044692.2] (tabel 1).

Menurut Ventura et al., 2007 bahwa Bifidobacterium adalah bakteri gram positif dari filum Actinobacteria, umumnya diisolasi dari gastrointestinal mamalia, serangga atau burung. Menurut Makino et al. 2013, Bifidobacterium telah ditemukan berasal dari saluran pencernaan manusia, vagina dan saluran kandung kemih, yang berfungsi menjaga keseimbangan mikro flora dalam usus, mengontrol peningkatan bakteri merugikan, memperkuat sistem kekebalan tubuh, dan membantu proses pencernaan. Menurut Maidak et.al., 2001, beberapa spesies dari genus Bifidobacterium telah digunakan selama beberapa dekade sebagai makanan fungsional untuk kesehatan atau efek probiotik. Probiotik dapat mereduksi terjadinya infeksi yang disebabkan oleh bakteri atau virus penyebab diare, menyembuhkan penyakit inflamasi kronis, meningkatkan kondisi fisiologi dan mengurangi resiko yang berdampak pada kesehatan (Marco, et.al., 2006).

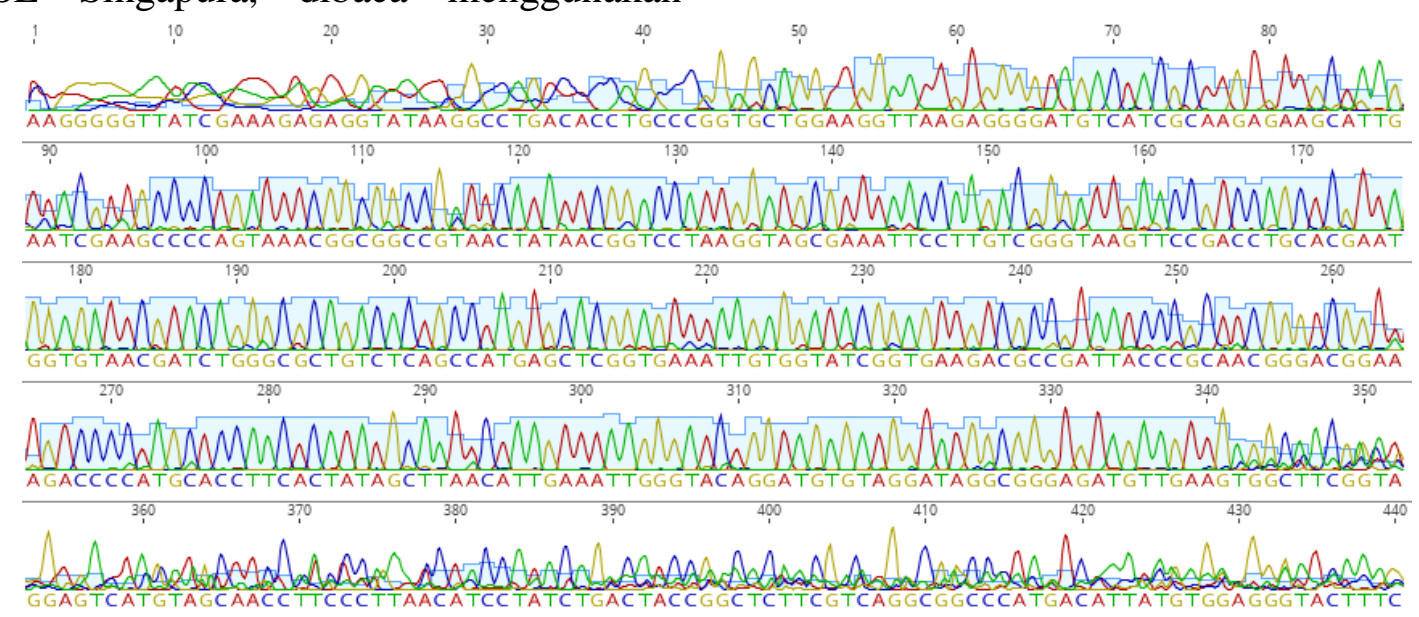

Gambar 3. Kromatogram Hasil Sekuensing Gen 16 S rRNA Isolat 
Tabel 1. Hasil BLAST Isolat

\begin{tabular}{|c|c|c|c|c|c|c|}
\hline Description & $\begin{array}{l}\text { Max } \\
\text { score }\end{array}$ & $\begin{array}{l}\text { Total } \\
\text { score }\end{array}$ & $\begin{array}{l}\text { Query } \\
\text { cover }\end{array}$ & $\begin{array}{l}\mathrm{E} \\
\text { value }\end{array}$ & Ident & Accession \\
\hline $\begin{array}{l}\text { Bifidobacterium minimum strain ATCC } \\
2753816 \text { S ribosomal RNA, partial } \\
\text { sequence }\end{array}$ & 31.8 & 31.8 & $3 \%$ & 4.9 & $90 \%$ & $\underline{\text { NR } 044692.2}$ \\
\hline $\begin{array}{l}\text { Empedobacter brevis strain LMG } 4011 \text { 16S } \\
\text { ribosomal RNA gene, partial sequence }\end{array}$ & 31.8 & 31.8 & $2 \%$ & 4.9 & $100 \%$ & $\underline{\text { NR } 042471.2}$ \\
\hline $\begin{array}{l}\text { Alistipes timonensis strain JC136 16S } \\
\text { ribosomal RNA gene, partial sequence }\end{array}$ & 31.8 & 31.8 & $2 \%$ & 4.9 & $94 \%$ & NR_125589.1 \\
\hline $\begin{array}{l}\text { Empedobacter brevis strain NBRC } 14943 \\
16 \text { S ribosomal RNA gene, partial } \\
\text { sequence }\end{array}$ & 31.8 & 31.8 & $2 \%$ & 4.9 & $100 \%$ & $\underline{\text { NR_112974.1 }}$ \\
\hline $\begin{array}{l}\text { Salinicoccus sesuvii strain CC-SPL15-2 } \\
16 \text { r ribosomal RNA gene, partial } \\
\text { sequence }\end{array}$ & 31.8 & 31.8 & $2 \%$ & 4.9 & $94 \%$ & $\underline{\text { NR_108493.1 }}$ \\
\hline
\end{tabular}

Bifidobacterium merupakan bakteri penghasil asam laktat. asam asetat, vitamin, bakteriosin. Asam laktat dapat menghambat pertumbuhan bakteri-bakteri penyebab penyakit (bakteri patogen). Selain itu, bakteri asam laktat juga dapat menghasilkan senyawa antimikroba lainnya seperti bakteriosin, reuterin, hidrogen peroksida dan diasetil. Bakteriosin adalah polipeptida yang memiliki aktivitas antimikroba.
3. Aktivitas Senyawa Antimokroba yang Dihasilkan Isolat Terhadap Bakteri Uji

Pengujian aktivitas antimikroba dilakukan dengan metode difusi. Tujuan dari pengujian ini adalah untuk mengetahui aktivitas isolat bakteri terhadap mikroba uji. Pada penelitian ini digunakan 4 jenis bakteri uji yaitu : Pseudomonas aeroginosa, Staphylococcus aureus, Escherichia coli, dan Providencia stuartii

\begin{tabular}{|l|l|l|l|}
\hline P. aeroginosa & S. aureus & E. coli & P. stuartii \\
\hline 2 & 2 & & \\
\hline
\end{tabular}

Adapun rata-rata lebar zona hambat dari senyawa antimikroba yang dihasilkan oleh isolat bakteri penghasil antimikroba yang berhasil diisolasi terhadap bakteri uji yaitu: $P$. aeroginosa $7 \mathrm{~mm}, S$. aureus $5 \mathrm{~mm}, E$. coli $11,5 \mathrm{~mm}$ dan $P$. stuartii $14 \mathrm{~mm}$. Zona hambat isolat yang paling kuat adalah terhadap bakteri $P$. stuartii. Lebar zona hambat isolat yang didapatkan pada penelitian ini masih tergolong rendah yaitu berkisar antara 5-14 mm. Hal ini disebabkan karena isolat penghasil antimikroba yang diperoleh hanya difermentasi pada media
Nutrient Broth (NB) sebagai media dasar tanpa dilakukan optimasi berbagai kondisi fermentasi seperti media, waktu dan $\mathrm{pH}$. Proses isolasi antimikroba/antibiotik yang efektif, maka perlu dilakukan berbagai optimasi kondisi fermentasi. Media, waktu dan $\mathrm{pH}$ fermentasi merupakan faktor penting yang harus dioptimasi. Menurut Sulistiyani (2006), produksi antibotik/antimikroba yang optimal dapat diperoleh dengan memperhatikan faktor waktu fermentasi, mengatur $\mathrm{pH}$ dan media pertumbuhan yang baik. $\mathrm{pH}$ berpengaruh 
terhadap aktivitas enzim yang memproduksi antibiotik, sedangkan waktu fermentasi dan media berpengaruh terhadap fase-fase pertumbuhan mikroorganisme. Pada penelitian ini belum mencakup proses optimasi-optimasi tersebut. Menurut Hugo (2004), salah satu fase hidup dari bakteri adalah fase stasioner dimana bakteri akan memproduksi metabolit guna mempertahankan diri dari bakteri lainnya karena pada fase ini mulai terjadi persaingan untuk mendapatkan nutrisi. Metabolit yang dihasilkan ini dapat membunuh atau menghambat pertumbuhan mikroorganisme lain yang berada di sekitar koloni. Hal ini dapat ditunjukkan dengan adanya zona bening di sekitar koloni tersebut.

\section{Kesimpulan}

Berdasarkan hasil penelitian yang telah dilakukan dapat diambil kesimpulan sebagai berikut :

1. Berhasil diisolasi satu isolat bakteri penghasil antimikroba dari saluran pencernaan lalat $C$. megachepala, melalui identifikasi molekuler dengan menggunakan gen 16S rRNA, menunjukkan bahwa isolat tersebut memiliki kemiripan $90 \%$ dengan Bifidobacterium minimum [NR 044692.2].

2. Isolat bakteri penghasil antimikroba yang diperoleh dapat menghambat $P$. aeroginosa, S.aureus, E. coli, dan Providencia stuartii. Zona hambat yang paling besar adalah terhadap $P$. stuartii.

\section{Daftar Pustaka}

Boman, H.G. 1995. Peptida antibiotic and role in innate immunity. Ann Rev Immunol 1995. 13: 61-92

Bulet, P., Hetru C., Dimarq J-L, Hoffmann D. 1999. Antimicrobial peptide in insects: structure fuction. Dev Comp Immunol 23 (45): 329-44.

Cognato. A.L.,and A.P. Volger. 2001. Exploring date interaction data and nucleotide aligment in a multiple gene analysis of lps (Coleopra: Scolytinae). Syst. Bio.5-:758 (50:758 - 780.

Depkes RI. 1991. Petunjuk Teknis Pemberantasan Lalat. Jakarta.
Liang, Y. L., J. X. Wang, X. F. Zhao, X. J. Du, and J. F. Xue. 2006. Molecular cloning and characterization of cecropin from the housefly (Musca domestica), and its expression in Escherichia coli. Dev. Comp. Immunol. 30: 249-257. Cross Ref, PubMed.

Maidak, B.L. J.R. Cole, T.G. Lilburn, C.T. Parker, P.R.Saxman, R.J. Farris, G.M. Garrity, G.J. Olsen, T.M. Schmidt, dan J.M. Tiedje. 2001. The RDP-II (Ribosomal Database Project). Nucleic Acids Res. 29:173-174.

Makino, Hiroshi, Akira Kushiro, Eiji Ishikawa, Hiroyuki Kubota, Agata Gawad, Takafumi Sakai, Kenji Oishi. 2003. "Mother-to-Infant transmission of intestinal bifidobacterial strains has an impact on the early development of vaginally delivered infant's microbiota." PloS one 8, no. 11: e78331.

Manuahe C, YS. Mokosuli and VIY. Roring. 2016. Optimization of DNA extraction and the position of mosquito Species from southeast Minahasa in North Sulawesi using NADH dehydrogenase Gene and Cytochrome oxidase Sub Unit 1 Gene. Journal of Entomology and Zoology Studies 2016; 4(4): 498-508.

Marco,M.L., S. Pavan, dan M. Kleerebezem. 2006. Towards understanding molecular modes of probiotic action. Curr. Opin. Biotechnol. 17:204-210.

Nuroniyah T, Rosa S. 2012. Identifikasi Spesies Isolat Bakteri S1 dengan Metode Analisis Sekuen Fragmen Gen 16S-rDNA. Jurnal Teknik Pomits. 2012;1(1):1-6.

Prescott, Harley, Klein. 2002. Microbiology. Fifth Edition.New York: The McGraw-Hill Companies.

Rachdie, Abu Salma Muhammad. 2007. "Mukjizat Hadits Lalat, Studi Ilmiah Hadits Lalat dalam Perspektif Islam dan Ilmu Medis Modern". Maktabah lit Tahmil: Malang

Ventura, M., C. Canchaya, A. Tauch, G. Chandra, K. Chater, G.F. Fitzgerald, dan D. Van Sinderen. 2007. Genomics of Actinobacteria: tracing the evolutionary history of an ancient phylum. Microbiol. Mol. Biol. Rev. 71:495-548.

Zasloff, M. 2002. Antimicrobial peptides of multicellular organisme. Nature 15(6870): 389-95. 